\title{
Penggunaan Bahasa MIDI Dalam Pembuatan Jinggle SPBU
}

\author{
Pandan Pareanom Purwacandra \\ Program Studi Animasi, Fakultas Seni Media Rekam, \\ Institut Seni Indonesia Yogyakarta \\ e-mail: pianisganteng@yahoo.com
}

\begin{abstract}
Abstrak
MIDI mampu mengolah banyak suara ke dalam satu aplikasi termasuk jenis-jenis instrumen yang dapat dihasilkan dan disediakan oleh suatu perangkat musik digital atau dapat juga dipadukan beberapa atau semua instrumen tersebut ke dalam satu aplikasi, sehingga efisiensi suara dapat dihasilkan dengan monitoring yang lebih tertata dan kualitas kejernihan suara mampu diperoleh dalam pembuatan maupun pengeditan. Penelitian ini dilakukan dalam rangka membuat sebuah Jingle di salah satu SPBU di Merbung, Klaten. Dengan menggunakan teknologi MIDI, maka jingle yang dihasilkan akan lebih murah namun tetap berkualitas. Selain itu, jingle yang dibuat melalui aplikasi MIDI dapat dengan mudah di edit dan di update. Instrument digital music pun menyerupai instrument aslinya.
\end{abstract}

Kata kunci: MIDI, jingle, instrument, digital music, gas station

\begin{abstract}
MIDI can process a number of sound into one software including types of instrument that can be produced dan provided by a digital music device or can be combined some or all instruments into one application, so the efficiency of the sound can be produced by a well-managed monitoring and the quality of voice clarity can be obtained in making and or editing. This study is conducted in order to create a Jingle in a gas station in Merbung, Klaten. By using MIDI technology, the jingle produced will be cheaper but still qualified. Additionally, jingle created via MIDI applications can be easily edited and updated. Instrument digital music even resembles the original instrument.
\end{abstract}

Keywords: MIDI, jingle, instrument, digital music, gas station 